\title{
ANALISIS IMPLEMENTASI PENILAIAN KINERJA PEGAWAI DENGAN SISTEM MANAJEMEN KINERJA PEGAWAI NASIONAL (SIMKPNAS) DI PT PLN (PERSERO) WILAYAH MALUKU DAN MALUKU UTARA
}

\author{
Ariviana L.Kakerissa \\ Program Studi Teknik Industri, Fakultas Teknik Universitas Pattimura, Ambon \\ N. E. Maitimu \\ Program Studi Teknik Industri, Fakultas Teknik Universitas Pattimura, Ambon \\ Erlin Sampulawa \\ PLN Wilayah Maluku dan Maluku Utara, Ambon
}

\begin{abstract}
ABSTRAK
Sistem penilaian kinerja pegawai merupakan salah satu cara peningkatan kualitas sumber daya manusia yang berdampak pada peningkatan produktivitas perusahaan PT PLN (Persero) Wilayah Maluku dan Maluku Utara. PT PLN (Persero) Wilayah Maluku dan Maluku Utara menerapkan sistem penilaian kinerja pegawai menggunakan Aplikasi Sistem Manajemen Kinerja Pegawai Nasional (SIMKPNAS) untuk mengevaluasi atau mengukur kinerja pegawai. aplikasi ini sebagai wadah yang menyediakan form untuk dapat mendukung seluruh aktivitas penilaian kinerja pegawai PT PLN (Persero) mulai dari tahap perencanaan, tahap pengukuran serta menyimpan hasil penilaian itu sendiri. Penulisan tugas akhir ini bertujuan menganalisa sistem penilaian kinerja pegawai pada PT PLN (Persero) Wilayah Maluku dan Maluku Utara. Data yang digunakan adalah data primer dan data sekunder melalui studi lapangan yaitu observasi, wawancara, dan studi kepustakaan, sedangkan teknik analisis data yang digunakan adalah teknis analisis data deskriptif. Berdasarkan hasil pengolahan data yang diperoleh dapat disimpulkan bahwa penilaian kinerja pada PT PLN (Persero) Wilayah Maluku dan Maluku Utara dilakukan dua kali dalam setahun. Penilaian kinerja pada PT PLN (Persero) Wilayah Maluku dan Maluku Utara ada dua jenis yakni penilaian hardskill dan penilaian softskill. Penilaian hardskill dinilai dari sasaran kinerja pegawai dan penilaian softskill dinilai dari kompetensi pegawai. Kedua jenis penilaian tersebut dimasukkan kedalam Aplikasi SIMKPNAS mulai dari perencanaan, pemantauan dan penilaian.
\end{abstract}

Kata Kunci: Kualitas, Penilaian Kinerja, SIMKPNAS

\begin{abstract}
Employee performance appraisal system is one way to improve the quality of human resources that has an impact on increasing the productivity of the company PT PLN (Persero) Maluku and North Maluku Region. The company implements the system using the National Employee Performance Management System Application (SIMKPNAS) to evaluate or measure employee performance. This application provides a form to be able to support all employee performance appraisal activities of PT PLN (Persero) starting from the planning stage, the measurement stage and storing the results of the assessment itself. This study aims to analyze the employee performance appraisal system at PT PLN (Persero) Maluku and North Maluku Region. The data consist of primary data and secondary data which is collected through field studies namely observation, interviews, and literature studies. Data were analyzed using descriptive data analysis techniques. Based on the results, it can be concluded that the performance appraisal is conducted twice a year including hard and soft skill assessment. Hard skill assessment is assessed from employee performance goals and soft skill assessment is assessed from employee competency. Both types of assessments are included in the SIMKPNAS application starting from planning, monitoring and evaluation.
\end{abstract}

Keywords: Quality, Performance Assessment, SIMKPNAS

\section{PENDAHULUAN}

Kesuksesan suatu perusahaan sangat bergantung pada aktifitas dan kreatifitas sumber daya manusia yang ada dalam perusahaan untuk mencapai visi dan misinya. Untuk itu perusahaan membutuhkan sumber daya manusia yang memiliki pengetahuan, keahlian dan keterampilan sesuai dengan bidangnya. Sumber daya manusia dalam organisasi biasa disebut pegawai atau pegawai. Pegawai yang dibutuhkan oleh suatu organisasi adalah pegawai potensial yang memiliki kinerja yang baik. 
Setiap perusahaan tentu berusaha membuat sebuah sistem penilaian kinerja yang bagus agar dapat menggambarkan kinerja para pegawainya dengan baik. Karena itu perusahaan perlu membuat konsep yang matang tentang sistem penilaian kinerja yang akan dipakai. Tahapan-tahapan apa saja yang diperlukan dan bagaimana cara pelaksanaannya. Pada penelitian yang dilakukan oleh Dick Grote (2002) disebutkan bahwa sistem penilaian kinerja yang bagus memiliki 4 fase yaitu performance planning (perencanaan kinerja), performance execution (eksekusi kinerja), performance assessment (penilaian kinerja), dan performance review (tinjauan kinerja).

Pandangan lain tentang penilaian kinerja pegawai juga diungkapkan oleh Rachmawati (2007), yang mengartikan penilaian kinerja adalah proses dimana organisasi menilai atau mengevaluasi kinerja pegawai. Penilaian tersebut dapat dilakukan setiap hari, bulanan ataupun tahunan. Dengan adanya penilaian kinerja pegawai ini dapat menunjukkan apakah sumber daya manusia ini telah memenuhi tuntutan yang diinginkan perusahaan.

PT PLN (Persero) merupakan salah satu perusahaan perseroan milik negara yang bergerak dibidang ketenagalistrikan, yang bergerak dalam sektor pembangkitan, transmisi dan distribusi tenaga listrik diseluruh Indonesia, baik di daerah perkotaan maupun di daerah pedesaan, baik dikalangan industri, komersial, rumah tangga, maupun umum. Dengan kata lain PT PLN (Persero) merupakan salah satu badan usaha milik negara dengan skala nasional yang bertanggung jawab memenuhi kebutuhan tenaga listrik diseluruh Indonesia. PT PLN (Persero) sebagai instansi yang memiliki tanggung jawab besar dalam melayani masyarakat sehingga harus memiliki pegawai yang potensial. Untuk meningkatkan potensi tersebut, PT PLN (Persero) juga melakukan penilaian kinerja kepada pegawainya.

Mayoritas perusahaan besar termasuk PT PLN (Persero) Wilayah Maluku dan Maluku Utara telah memiliki sistem penilaian kinerja yang dirancang sesuai teori-teori tersebut. Pada PT PLN (Persero) Wilayah Maluku dan Maluku Utara penilaian kinerja pegawai dilakukan setiap akhir semester. Dahulu sistem penilaian kinerja di PT PLN (Persero) Wilayah Maluku dan Maluku Utara dinamakan SMUK (Sistem Manajemen Unjuk Kerja). Pada pertengahan tahun 2012, sistem ini diubah menjadi SIMKPNAS (Sistem Manajemen Kinerja Pegawai Nasional). Secara garis besar sistemnya tidak terlalu berbeda. Perubahan ini dilakukan tentu untuk memperbaiki kekurangan pada sistem yang lama yaitu belum terdapatnya target kinerja setiap individu yang sesuai dengan jabatan serta target kinerja yang dapat dirubah oleh individu itu sendiri.

Sebenarnya apakah yang membuat sistem penilaian kinerja pada PT PLN (Persero) Wilayah Maluku dan Maluku Utara dianggap belum sesuai dan apakah sistem penilaian yang sekarang sudah dilaksanakan dengan baik sesuai dengan teori cara pelaksanaan penilaian kinerja atau belum. Berdasarkan hasil wawancara dengan beberapan pegawai (Manajer dan Staff) tentang penilaian kinerja dengan aplikasi SIMKPNAS bahwa terdapat permasalahan dan kendala. Kendala dan permasalahan tersebut berupa kurangnya sosialisasi mengenai proses pembuatan, penilaian, verifikasi dan evaluasi yang di lakukan. Permasalahan lain yang terlihat adalah adanya perbedaan beban kerja pada setiap bidang, dimana ada beberapa bidang yang memiliki beban kerja tetap atau rutin setiap hari kerja dan ada juga beberapa bidang yang memiliki beban kerja yang sedikit karena pekerjaannya yang terjadwal. Sehingga dalam melakukan penilaian tersebut mengandung unsur rekayasa dan formalitas semata. Oleh sebab itu, sistem penilaian pegawai menggunakan aplikasi SIMKPNAS perlu ditinjau kembali karena apabila kinerja pegawai pada bidang tersebut rendah, maka tujuan organisasi tentu tidak tercapai dengan maksimal. Pada penelitian ini, peneliti akan mencoba menggali bagaimanakah pandangan para pegawai PT PLN (Persero) Wilayah Maluku dan Maluku Utara terhadap sistem penilaian kinerja yang ada.

Tujuan penelitian ini yaitu untuk mengetahui penerapan penilaian kinerja pegawai dan memberikan umpan balik dalam upaya memperbaiki penilaian kinerja pegawai, Mencari solusi untuk mengatasi masalah atau kendala dalam penilaian kinerja pegawai menggunakan aplikasi SIMKPNAS pada PT PLN (Persero) Wilayah Maluku dan Maluku Utara serta Perbaikan pengukuran kinerja pegawai yang mencerminkan kinerja individu yang sesungguhnya.

\section{LANDASAN TEORI}

\section{Pengertian Penilaian Kinerja}

Penilaian kinerja bisa didefinisikan sebagai prosedur yang meliputi penetapan standar kerja, penilaian kinerja aktual pegawai dalam hubungan dengan standar-standar, dan pemberian umpan balik kepada pegawai dengan tujuan memotivasi orang tersebut untuk menghilangkan kemerosotan kinerja atau terus berkinerja lebih tinggi lagi (Dessler, 2013, hal.321). 
Menurut Siagian (2003) menekankan bahwa penilaian merupakan upaya pembanding antara hasil yang nyata dicapai setelah satu tahap tertentu selesai dikerjakan dengan hasil yang seharusnya dicapai untuk tahap tersebut. Definisi tersebut menunjuk kepada lima hal yaitu :

1. Penilaian berbeda dengan pengawasan yang sorotan perhatiannya ditujukan pada kegiatan operasional yang sedang diselenggarakan, sedangkan penilaian dilakukan setelah satu tahap tertentu dilalui.

2. Penilaian menghasilkan informasi tentang tepat tidaknya semua komponen dalam proses manajerial, mulai dari tepat tidaknya tujuan hingga pelaksanaan kegiatan pengawasan.

3. Hasil penilaian menggambarkan apakah hasil yang dicapai sama dengan sasaran yang telah ditentukan, melebihi sasaran atau malah kurang dari sasaran.

4. Informasi yang diperoleh dari kegiatan penilaian diperlukan untuk mengkaji ulang semua komponen proses manajerial sehingga perumusan kembali berbagai komponen tersebut dapat dilakukan dengan tepat.

5. Orientasi penilaian adalah masa depan yang pada gilirannya memungkinkan organisasi meningkatkan kinerjanya.

\section{Tujuan Penilaian Kinerja}

Tujuan dilakukannya penilaian kinerja secara umum adalah untuk memberikan feedback kepada pegawai dalam upaya memperbaiki tampilan kerjanya dan upaya meningkatkan produktivitas organisasi dan secara khusus dilakukan dalam kaitannya dengan berbagai kebijaksanaan terhadap pegawai seperti untuk tujuan promosi, kenaikan gaji, pendidikan dan latihan dan lain-lain.

Evaluasi kinerja atau penilaian kinerja perlu dilakukan karena penilaian kinerja dapat memberikan informasi kepada manajemen mengenai dapat dilakukannya promosi dan kenaikan gaji kepada seorang pegawai atau tidak. Selain itu penilaian memberi peluang bagi manajer dan pegawai untuk meninjau hubungan kerja dengan bawahannya. Penilaian kinerja memungkinkan tergalinya kekurangan-kekurangan yang ada dalam kinerja, dan dari sini atasan dan bawahan dapat bersama-sama membuat rencana untuk memperbaiki kekurangan-kekurangan tersebut. Secara jangka panjang penilaian juga memberi peluang yang baik untuk meninjau rencana karier pegawai.

Sedangkan menurut Sastrohadiwiryo (2003) mengemukakan bahwa penilaian kinerja dilakukan dengan tujuan sebagai:

1. Sumber data untuk perencanaan ketenagakerjaan dan kegiatan pengembangan jangka panjang bagi perusahaan yang bersangkutan.

2. Nasihat yang perlu disampaikan kepada para tenaga kerja dalam perusahaan.

3. Alat untuk memberikan umpan balik (feed back) yang mendorong ke arah kemajuan dan kemungkinan memperbaiki atau meningkatkan kualitas kerja bagi para tenaga kerja.

4. Salah satu cara untuk menetapkan kinerja yang diharapkan dari seorang pemegang tugas dan pekerjaan.

5. Landasan/bahan informasi dalam pengambilan keputusan pada bidang ketenagakerjaan, baik promosi, mutasi, maupun kegiatan ketenagakerjaan lainnya.

6. Standar dalam penentuan tinggi rendahnya kompensasi serta administrasi bagi tenaga kerja.

Peningkatan Penilaian Kinerja

Dalam penelitian yang dilakukan oleh (Goodale, 1992, hal.66) didapatkan bahwa ada tujuh pedoman dalam meningkatkan proses penilaian kinerja. Pedoman yang pertama yaitu pada proses pembuatan desain sistem penilaian kinerja. Agar dapat mendapatkan sistem penilaian kinerja yang baik, manajer dan pegawai harus dilibatkan dalam proses pendesainan ini. Hal ini agar nantinya proses penilaian dapat berjalan sesuai harapan baik manajemen maupun pegawai. Kemudian pada proses pendesaianan, manajemen harus membuat tujuan-tujuan yang jelas pada penilaian kinerja dan menempatkan titik berat yang tepat pada masing-masing tujuan. Kemudian pada proses pemberian umpan balik, umpan balik harus difokuskan pada hasil dan kinerja yang dapat diobservasi dan berkaitan dengan pekerjaan. Sebaiknya menghindari pemberian timbal balik yang bersifat personal.

\section{Metode Pengukuran Kinerja}

Metode khusus yang digunakan pada PT PLN (Persero) Wilayah Maluku dan Maluku Utara ini menggunakan metode Management By Objective (MBO) dan metode penilaian tradisional. Metode Management By Objective (MBO) atau manajemen berdasarkan sasaran merupakan suatu penilaian kinerja pegawai dengan cara menentukan tujuan-tujuan atau sasaran-sasaran kinerja yang dibuat oleh pegawai untuk mencapai kinerja dalam periode tertentu. Dimana pada tahap ini pegawai dan atasan langsung membuat target kerja untuk satu semester (enam bulan), sehingga pekerjaan yang dilakukan 
dalam satu semester tersebut lebih terarah. Sedangkan Metode tradisional yang sesuai dengan data dilapangan adalah rating scale. Menurut Hasibuan (2002:96) Rating scale adalah merupakan metode penilaian yang paling tua dan banyak digunakan, di mana penilaian yang dilakukan oleh atasan atau supervisor untuk mengukur karakteristik, misalnya mengenai inisiatif, ketergantungan, kematangan dan kontribusinya terhadap tujuan kerjanya.

\section{Hambatan dalam penilaian kinerja}

Penilaian kinerja menyangkut kegiatan yang sarat dengan soal emosional, yakni penilaian terhadap kontribusi seseorang terhadap organisasi karena hasil penilaian kinerja ini dapat mempengaruhi harga diri dan bentuk kinerja masa yang akan datang. Setiap masalah yang didasarkan pada ukuran subjektif merupakan peluang terjadinya bias. Bias dari penilai terjadi ketika nilai-nilai atau prasangka dari penilai mempengaruhi penilaian. Bias penilai ini mungkin saja secara tidak sadar atau malah disengaja. Bentukbentuk bias yang umumnya terjadi dilingkup PT PLN (Persero) Wilayah Maluku dan Maluku Utara.
a. Hallo Effect (Kesan Pertama)
b. Error of Central Tendency (Kesalahan Akibat Kecenderungan Menilai di Tengah)
c. Leniency and Strictness Bias (Bias Terlalu Longgar atau terlalu Ketat)
d. Friendly (Kedekatan Hubungan)
e. Cross Cultural Bias (Bias Penyimpangan antara Budaya)
f. Personal Prejudice (Prasangka Pribadi)
g. Pengaruh-Pengaruh Organisasi
h. Recency Effect ( Kesan yang Sekarang)

\section{Upaya Mengatasi Hambatan Penilaian Kinerja}

Dalam mengatasi hambatan-hambatan dalam penilaian kinerja, harus benar-benar memperhatikan halhal berikut:

a. Tugas-tugas yang dinilai dalam penilaian kinerja harus sesuai (relevensi) dengan tugas-tugas yang harus dikerjakan oleh pekerja.

b. Penilaian kinerja harus memiliki kepekaan (sensitivitas) dalam membedakan pekerjaan yang efektif dengan yang tidak efektif.

c. Penilaian kinerja harus (reliabilitas) konsisten hasilnya jika dilakukan berulang-ulang dalam menilai seorang pekerja.

d. Hasil penilaian kinerja dapat dipakai atau terpakai, berhubungan dengan pelaksanaan pekerjaan oleh para pekerja (bersifat akseptabel).

e. Penilain kinerja harus praktis, didesain dalam bentuk yang mudah melaksanakannya.

f. Mengupayakan ketelitian.

g. Berfokus pada perilaku dan hasil, bukan pada sikap.

h. Bersikap jujur dan adil.

i. Bersikap rasional, jangan emosional.

\section{Kerangka Pemikiran}

Kerangka pemikiran yang dikembangkan dalam penelitian ini adalah sebagai berikut :

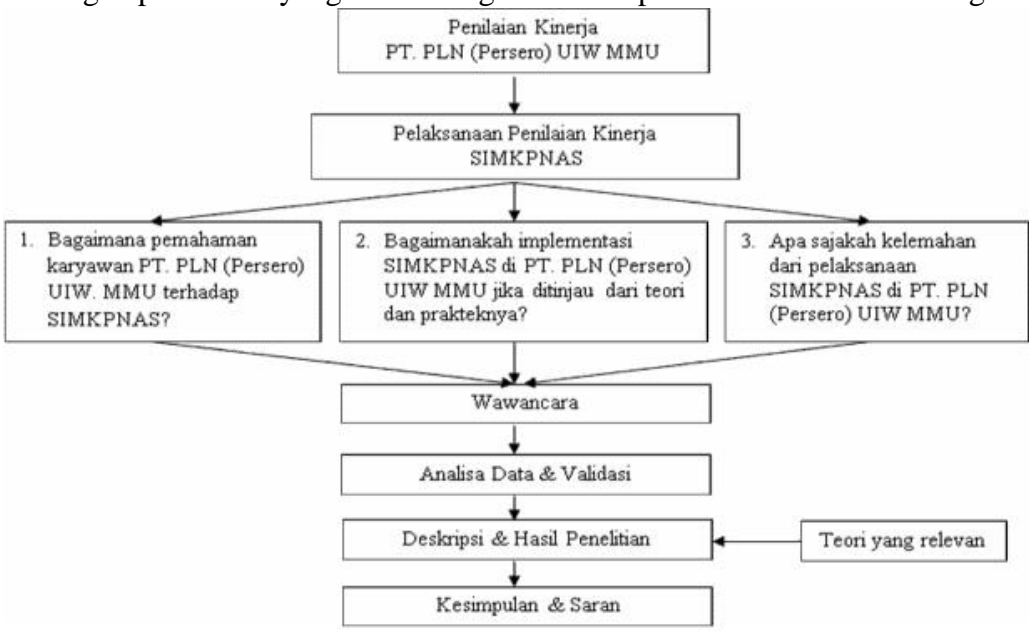

Kerangka Pemikiran 
METODE PENELITIAN

Metode Pengumpulan data

Dalam melakukan penelitian, metode pengumpulan data dapat dilakukan dengan cara sebagai berikut :

a. Data Primer atau Riset Lapangan (Field Research)

Menurut Sarwono (2006), data primer adalah data yang berasal dari sumber asli atau pertama. Pada penelitian ini penulis mengumpulkan data melalui: Observasi, Kuisioner, dan Wawancara

b. Data Sekunder atau Riset Kepustakaan (Library Research)

Data sekunder menurut Sarwono (2006) adalah data yang sudah tersedia sehingga kita tinggal mencari dan mengumpulkan. Penulis menggunakan data sekunder dengan mempelajari dokumendokumen perusahaan dan teori-teori yang ada dalam buku yang berhubungan dengan masalah yang sedang diteliti.

\section{Metode Analisa Data}

Metode yang digunakan dalam penelitian ini adalah metode penelitian kualitatif deskriptif. Pada penelitian ini ada dua jenis partisipan yang akan diteliti, yaitu partisipan yang merupakan staf sebagai sudut pandang bawahan yang dinilai dan partisipan yang menduduki jabatan struktural sebagai sudut pandang penilai (atasan) sekaligus sudut pandang bawahan. Metode penentuan subjek penelitian yang dipakai dalam penelitian ini adalah teknik purposive sampling (subjek sesuai tujuan). Berikut ini merupakan flowchart dari penelitian ini.

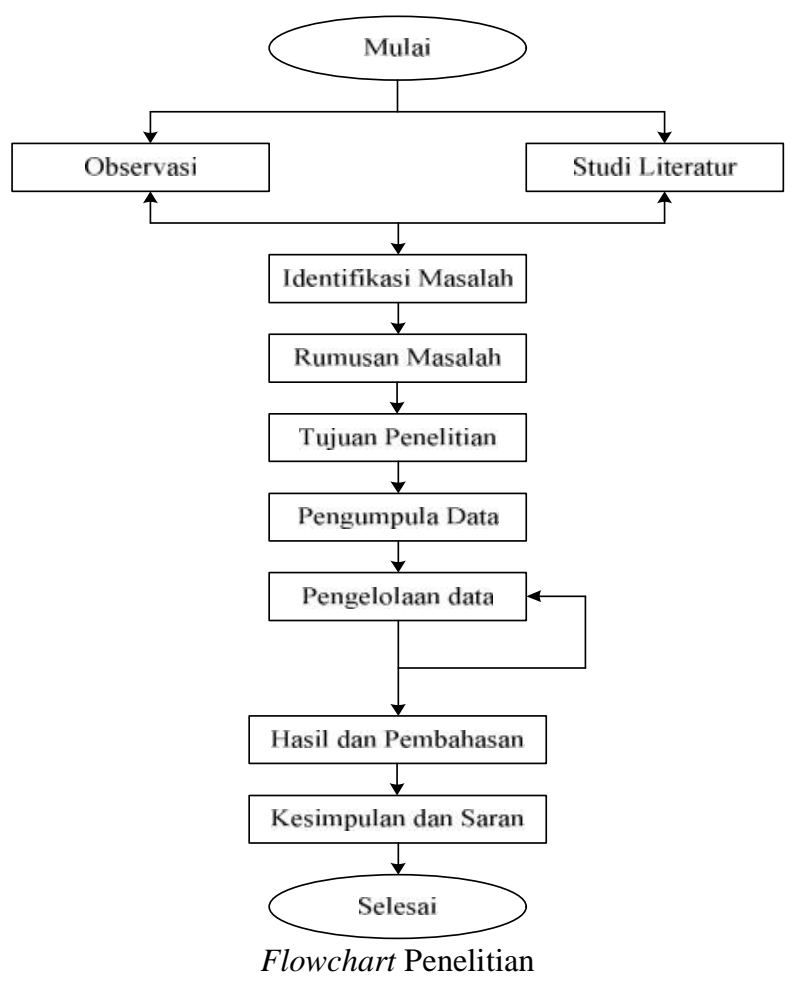

\section{HASIL DAN PEMBAHASAN}

Tahapan SIMKPNAS

Aplikasi Sistem Informasi Kinerja Pegawai Nasional (SIMKPNAS) adalah sebuah aplikasi yang digunakan khusus oleh PT PLN (Persero) untuk dokumentasi penilaian kinerja seluruh pegawai PT PLN (Persero).

Penilaian kinerja yang baik memerlukan suatu metode yang bisa menjadi tolak ukur dan pedoman dalam melakukan penilaian kinerja. Metode ini bertujuan agar kegiatan penilaian lebih terarah dan mengurangi kesalahan dalam penilaian. Penilaian kinerja pegawai pada PT PLN (Persero) Wilayah Maluku dan Maluku Utara ada dua jenis yakni penilaian hardskill dan softskill. Hardskill dinilai dari sasaran kinerja pegawai, sedangkan softskill dinilai dari kompetensi pegawai. Metode penilaian kinerja pegawai PT PLN (Persero) Wilayah Maluku dan Maluku Utara, yakni penilaian hardskill menggunakan 
metode MBO (Management By Objective), sedangkan penilaian softskill metode penilaiannya adalah skala peringkat (Rating Scale).

1. Metode MBO (Management By Objective)

Metode management by objective (MBO) atau manajemen berdasarkan sasaran merupakan suatu penilaian kinerja pegawai dengan cara menentukan tujuan-tujuan atau sasaran-sasaran kinerja yang dibuat oleh pegawai untuk mencapai kinerja dalam periode tertentu. Berdasarkan hasil wawancara Penulis dengan Manajer Bidang Kepegawaian PT PLN (Persero) Wilayah Maluku dan Maluku Utara ada tiga tahap dalam penilaian kinerja hardskill pegawai, yaitu:

a. Tahap Perencanaan Kinerja Pegawai

Pada tahap ini pegawai membuat sasaran kinerja atau target kerja pegawai dalam satu semester. Pembuatan sasaran kinerja tersebut berdasarkan tujuan organisasi, dimana KPI (Key Performance Indikator) unit dan KPI manajemen yang menjadi acuan untuk membuat sasaran kinerja. Adapun contoh sasaran kinerja yang diusul pegawai, dapat diihat pada tabel 1.

\section{Contoh Target Usulan Kinerja Pegawai}

\section{DATA SASARAN KINERJA PEGAWAI}

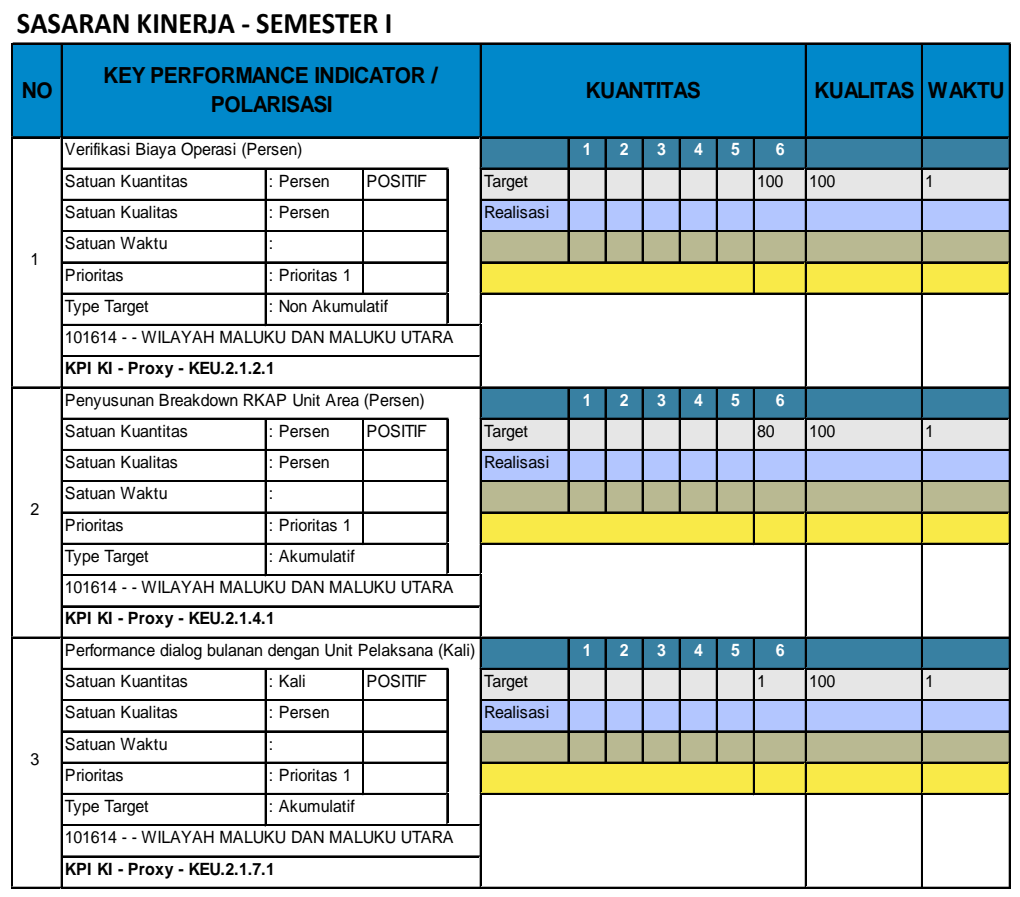

Berdasarkan contoh sasaran kinerja pada table 1 dapat dijelaskan sebagai berikut:

1) Identitas pegawai yang terdiri dari nama, jabatan, jenjang jabatan dan tahun dibuatnya sasaran kinerja.

2) Nomor merupakan urutan sasaran kinerja yang dibuat oleh pegawai. Sasaran kerja yang dibuat minimal lima dan maksimal delapan.

3) Tipe KPI, terdiri dari KPI Manajemen, Rutin atau Uraian Jabatan. KPI Manajemen/Proksi sudah tersedia pada sistem aplikasi namun tanpa turunannya. Rutin atau Uraian Jabatan merupakan pekerjaan rutin dimana akan ada perbedaan dalam pengisian targetnya.

4) Prioritas merupakan tingkat prioritas pengerjaan sasaran kinerja menyatakan tingkat urgensi, keluasan dampak, serta prioritas penyelesaian suatu sasaran kinerja yang dinyatakan berupa skor prioritas. Prioritas terdiri dari satu sampai lima.

b. Tahap Pemantauan Kinerja Pegawai

Pemantauan sasaran kinerja pegawai adalah periode diskusi formal antara pegawai dengan atasan langsung selama proses pencapaian sasaran kinerja pegawai. Pada tahap ini dilakukan tiga bulan setelah dilakukan perencanaan kinerja oleh pegawai. Jika pada saat dilakukannya pemantauan, ternyata rencana atau target yang telah dibuat terlaksana dua dari lima rencana yang telah dibuat. Maka atasan langsung memberikan motivasi terhadap pegawainya, agar tercapai target tersebut. Apabila rencana atau target yang telah dibuat, tidak ada satupun target yang telah dibuat tercapai, maka atasan langsung memberikan 
solusi terhadap pegawai tersebut. Jika target yang telah dibuat sulit untuk dicapai, atasan langsung beserta bawahannya harus membuat target kerja yang baru untuk tiga bulan kedepan. Pada tahap ini terjadi komunikasi antara pegawai dan atasan langsung. Dimana atasan langsung memberikan arahan, bimbingan, motivasi, dan pemantauan progres atau pencapaian kinerja pegawai.

c. Tahap Pengukuran Kinerja Pegawai

Pengukuran sasaran kinerja pegawai merupakan proses diskusi formal antara pegawai dengan atasan langsung yang dilakukan pada akhir siklus manajemen kinerja pegawai. Pada tahap ini, atasan langsung wajib memberikan penilaian secara objektif terhadap pencapaian target sasaran kinerja pegawai yang telah dibuat pada tahap perencanaan. Atasan langsung membandingkan target kerja dengan realisasi kerja yang telah dicapai. Indikator yang akan dinilai pada tahap ini yaitu waktu, kuantitas dan kualitas. Waktu yang dibuat pada saat perencanaan sebelumnya lebih cepat atau lambat dari target yang telah dibuat. Kuantitas dan kualitas yang dinilai apakah sesuai target yang dibuat dengan realisasi yang telah dicapai selama satu semester. Setelah dilakukan pengisian maka hasil perhitungan pencapaian otomatis akan tampil pada aplikasi seperti tabel 2

Contoh Perhitungan Sasaran Kinerja Pegawai

\section{DATA SASARAN KINERJA PEGAWAI}

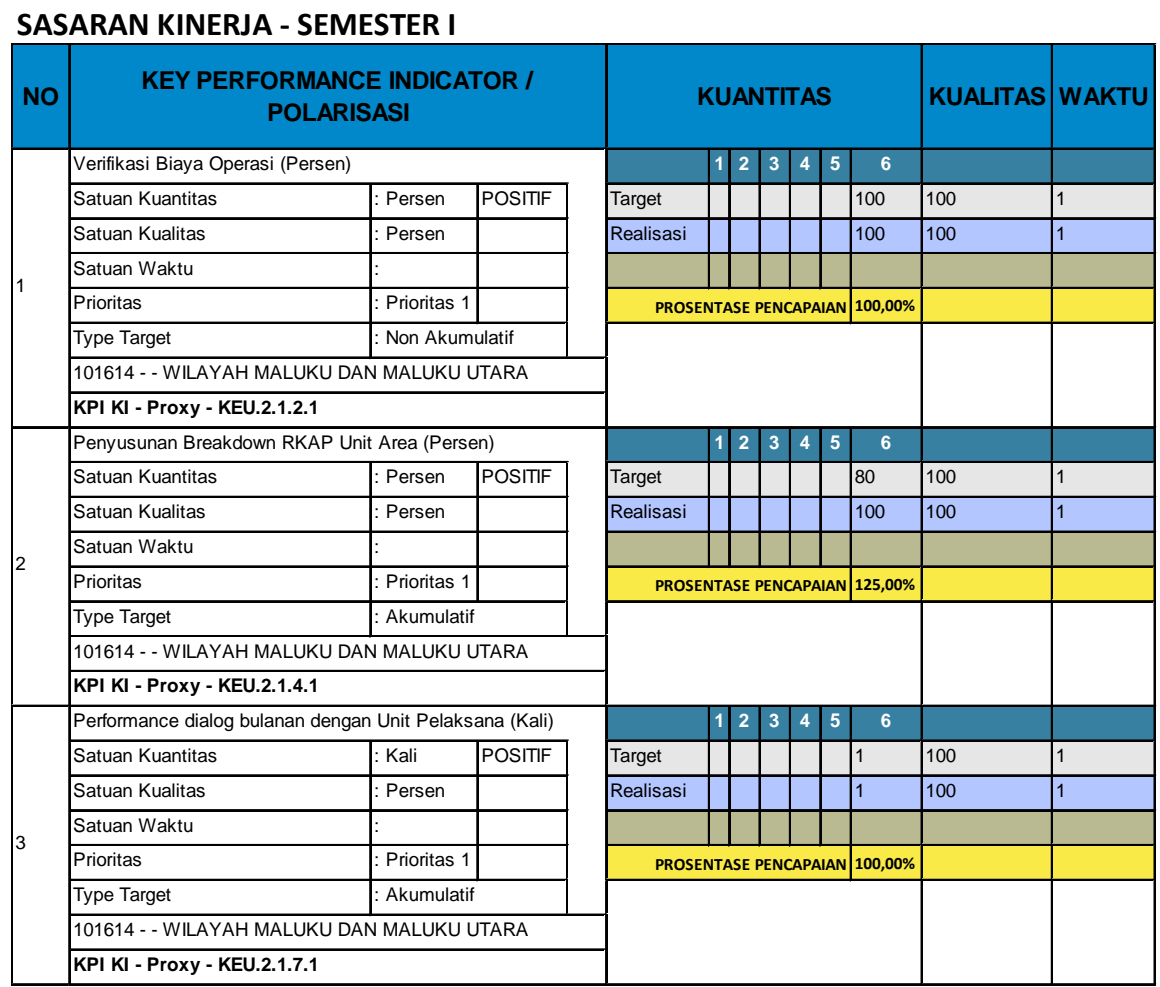

Berdasarkan tabel 2 dapat terlihat bagaimana pencapaian sasaran kinerja pegawai dalam satu semester. Nilai yang didapatkan dalam perhitungan pencapaian kinerja berupa persentase. Nilai ini otomatis akan tampil setelah pegawai mengisi kolom realisasi kerja. Berikut data pendukung pengisian pencapaian sasaran kinerja.

Pendukung Pencapaian Kinerja Verifikasi Biaya

\begin{tabular}{|c|c|c|c|c|c|c|c|c|}
\hline \multirow{2}{*}{ No. } & \multirow{2}{*}{ Revisi } & \multicolumn{2}{|c|}{ Nomor Nota Dinas } & \multicolumn{2}{|c|}{ Tanggal } & \multicolumn{2}{|c|}{ Hari } & \multirow{2}{*}{\begin{tabular}{|c|} 
Realisasi \\
$\%$ \\
\end{tabular}} \\
\hline & & User & Ren & usulan & proses & Prs & Maks & \\
\hline 1 & LKAO Niaga & 00046/AGA & 00080/KEU & 08-Feb-19 & $15-F e b-19$ & 5 & 5 & $100 \%$ \\
\hline 2 & LKAO Pembangkit & 00140/AGA & 00105/KEU & 28-Feb-19 & 07-Mar-19 & 5 & 5 & $100 \%$ \\
\hline 3 & LKAO Tata Usaha & 0211/AGA & 00122/KEU & 13-Mar-19 & 20-Mar-19 & 5 & 5 & $100 \%$ \\
\hline 4 & LKAO Pembangkit & 00350/KEU & 00217/KEU & 22-Mei-19 & 29-Mei-19 & 5 & 5 & $100 \%$ \\
\hline
\end{tabular}




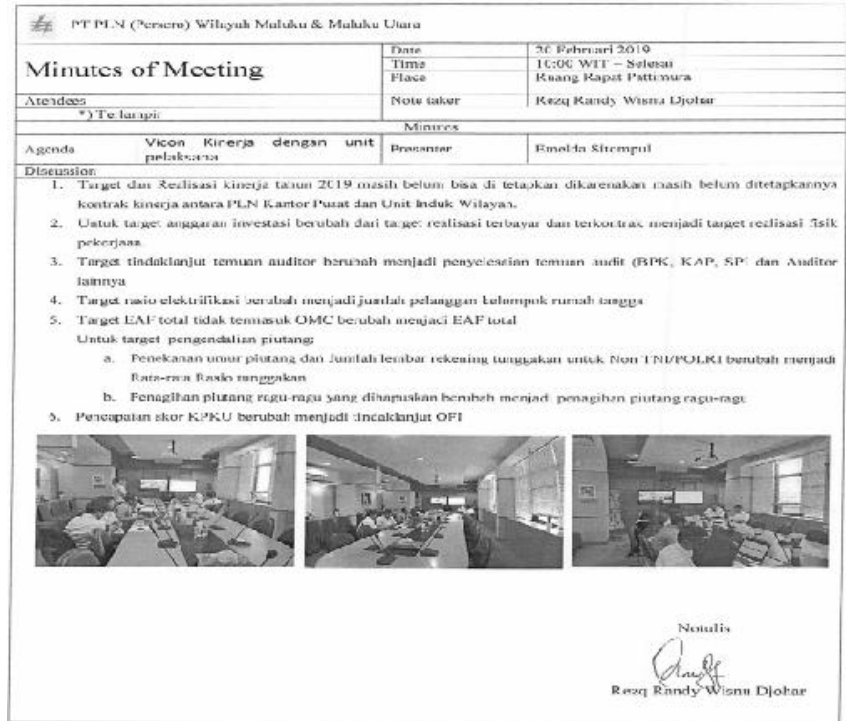

Gambar Pendukung Pencapaian Kinerja Performance Dialog

Untuk cara perhitungan manual dapat dicari dengan rumus sebagai berikut:

Wak

$=\begin{gathered}\text { Jumlah hari dalam penyelesaian tugas } \\ \text { Jumlah hari dalam enam bulan }\end{gathered} \times 100 \%$

Kuantitas $=\frac{\text { Jumlah realisasi target kerja }}{\text { Jumlah target yang diusulkan }} \times 100 \%$

Kualitas $=\frac{\text { Persentase realisasi kualitas kerja }}{\text { Persentase kualitas yang ditargetkan }} \times 100 \%$

Setelah itu diketahui berapa poin yang didapat dalam masing-masing sasaran kinerja. Poin tersebut dapat dilihat berdasarkan kriteria penilaian yang telah ditetapkan. Kriteria penilaian sasaran kinerja pegawai PT PLN (Persero) seperti pada tabel 4.

Kriteria Penilaian Sasaran Kinerja

\begin{tabular}{|c|c|c|}
\hline $\begin{array}{c}\text { Angka } \\
\text { Pain } \\
\text { Pencapaian }\end{array}$ & $\begin{array}{c}\text { Waktu Penyelesaian Tugas } \\
\text { Dibandingkan Target } \\
\text { Waktu Yang Ditetapkan }\end{array}$ & $\begin{array}{c}\text { Pencapaian Kualitas atau } \\
\text { Kuantitas Target } \\
(\%)\end{array}$ \\
\hline 400 & 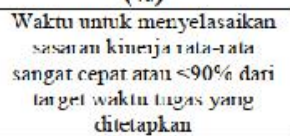 & 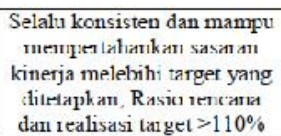 \\
\hline 300 & 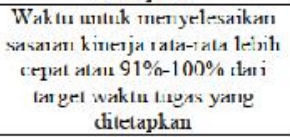 & 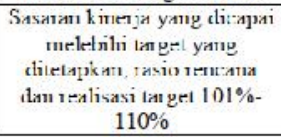 \\
\hline 200 & 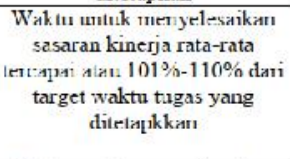 & 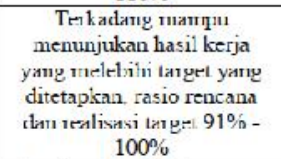 \\
\hline 100 & $\begin{array}{c}\text { Waklu untuk menyelesaikan } \\
\text { sasaran kinerja rata-rata tidak } \\
\text { tercapai dengan baik atau } \\
111 \% \text { - } 130 \% \text { dari target } \\
\text { waktu yang ditetapkan }\end{array}$ & $\begin{array}{c}\text { Lamban dam tidal mampu } \\
\text { memenuhi sasaran kimerja } \\
\text { sesuai target yang } \\
\text { ditetapkan. rasio rencana } \\
\text { dan realisasi target } 75 \% \text { - } \\
90 \%\end{array}$ \\
\hline 0 & $\begin{array}{c}\text { Waktu untuk menyelesaikan } \\
\text { sasaran kinerja rata-rata tidak } \\
\text { tercapai dengan baik atau } \\
131 \% \text { dari target waktu yang } \\
\text { ditetapkan }\end{array}$ & $\begin{array}{c}\text { Target tidak tercapai atau } \\
<75 \%\end{array}$ \\
\hline
\end{tabular}


Berdasarkan tabel 2 dan table 4, dapat diketahui bahwa cara mendapatkan nilai akhir dari sasaran kinerja yang didapatkan pegawai dengan cara menghitung nilai waktu, kuantitas dan kualitas dan dicari nilai rata-ratanya. Cara menghitung nilai rata-rata waktu, kuantitas dan kualitas adalah sebagai berikut:

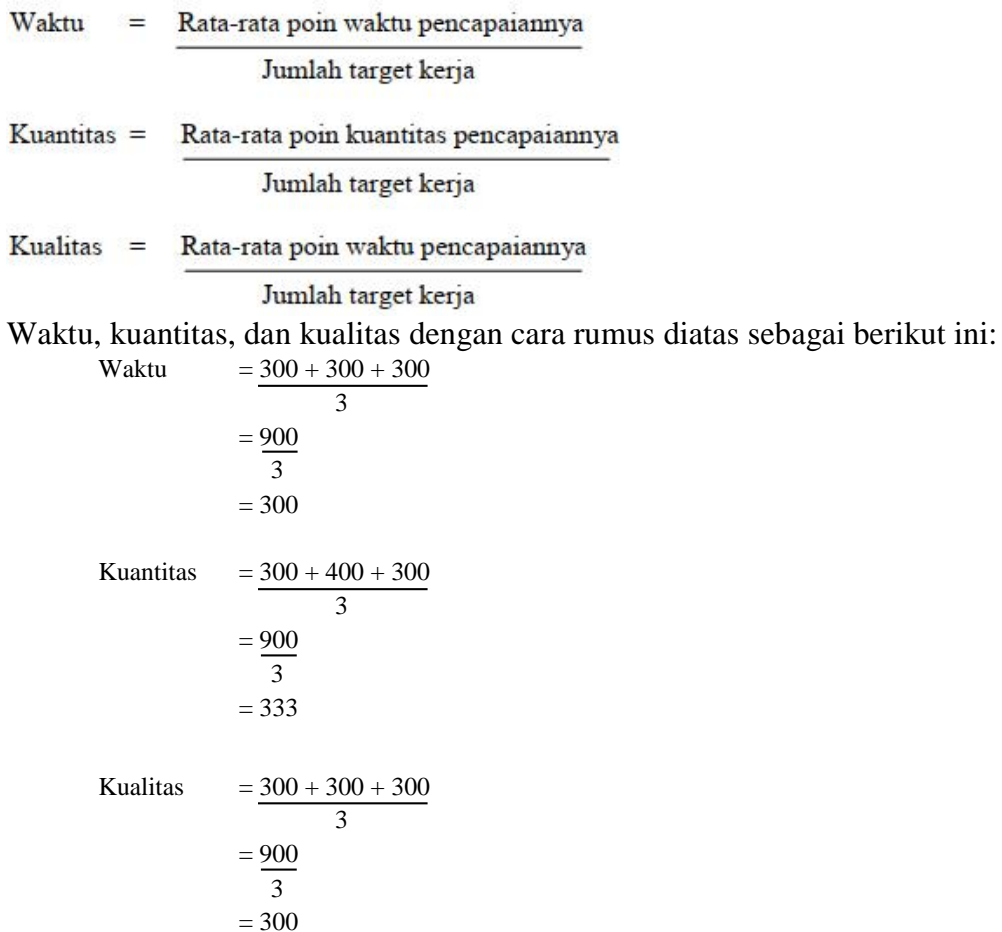

Setelah masing-masing nilai waktu, kuantitas, dan kualitas sudah diketahui, maka selanjutnya mencari nilai sasaran kinerja dengan cara :

Sasaran kinerja $=$ nilai waktu + nilai kuantitas + nilai kualitas

$$
\begin{aligned}
& =\frac{300+333+300}{3} \\
& =\frac{933}{3} \\
& =311
\end{aligned}
$$

Kemudian setelah nilai sasaran kinerja diketahui, maka pegawai akan mengetahui hasil pencapaian sasaran kinerjanya. Dari contoh diatas diketahui bahwa pegawai tersebut mendapatkan poin 311. Artinya bahwa pegawai tersebut berada direntang nilai "Melampaui Harapan" (Exceeds Requirements). Berikut tabel hasil penilaian sasaran kinerja pegawai dapat dilihat pada tabel berikut.

Daftar Hasil Akhir Penilaian Sasaran Kinerja Pegawai

\begin{tabular}{|c|l|c|}
\hline $\begin{array}{c}\text { Rentang Poin } \\
\text { Penilaian }\end{array}$ & \multicolumn{1}{|c|}{ Hasil Pengukuran Sasaran Kinerja } & Simbol \\
\hline $401-500$ & Pencapaian Luar Biasa (Outstanding) & OS \\
\hline $301-400$ & Melampaui Harapan (Exceeds Requirements) & ER \\
\hline $201-300$ & Memenuhi Persyaratan (Meet Requirements) & $\mathrm{MR}$ \\
\hline $101-200$ & Perlu Pengembangan (Need Improvement) & $\mathrm{NI}$ \\
\hline $0-100$ & Pencapaian Minimum (Marginal) & $\mathrm{MG}$ \\
\hline
\end{tabular}

Kebaikan dari metode ini adalah pegawai terlibat langsung dalam perencanaan sasaran kinerja, sehingga dalam bekerja pegawai sudah tau target apa yang akan dicapai dalam satu semester. Selain itu, akan mendorong pegawai untuk bekerja lebih efektif guna mencapai hasil yang diinginkan. 
2. Metode Skala Peringkat (Rating Scale)

Skala peringkat merupakan metode penilaian pegawai berdasarkan unsur-unsur yang telah ditetapkan oleh perusahaan, dimana penilaian dilakukan oleh atasan atau supervisor. Selain menilai kemampuan hardskill pegawai, PT PLN (Persero) juga menilai kemampuan softskill pegawainya. Penilaian softskill merupakan pertambahan nilai pegawai selain dari nilai sasaran kinerja. Penilaian softskill tersebut dinamakan Penilaian Kompetensi Individu. Penilaian kompetensi individu dilakukan pada saat akhir semester setelah dilakukannya penilaian sasaran kinerja pegawai. Penilaian kompetensi individu dilakukan dengan cara menggunakan kuesoner online yang akan diisi oleh atasan langsung pegawai yang bersangkutan.

Unsur atau Indikator yang dinilai pada kompetensi individu ada enam, yaitu:

a. Sikap

Sikap yang dinilai merupakan bagaimana sikap pegawai dalam mengatasi masalah dalam bekerja, kesopanan dan memperlihatkan sikap yang baik.

b. Pengetahuan

Pengetahuan yang dimaksud merupakan pengetahuan pegawai mengenai pekerjaan yang dikerjakan. Keseluruhan pengetahuan kompetensi pegawai akan menjadi bahan penilaian. Misalnya, pegawai bagian administrasi harus memiliki pengetahuan tentang surat menyurat dan apapun yang berhubungan dengan bidangnya.

c. Komuikasi

Komunikasi yang dinilai merupakan komunikasi berbicara antara sesama pegawai dan pegawai dengan atasan.

d. Kerjasama

Dalam bekerja pada sebuah perusahaan pasti memerlukan kerja sama tim. Kemampuan dan kesediaan pegawai dalam bekerja secara bersama-sama dengan orang lain juga dinilai. Kerjasama yang baik akan menghasilkan pekerjaan dan tingkat keberhasilan yang lebih tinggi.

e. Tanggung Jawab

Tanggung jawab merupakan hal yang sangat berhubungan dengan kepribadian seorang pegawai. Selain tanggung jawab pegawai terhadap pekerjaan, penilaian juga akan melihat kesadaran pegawai untuk selalu menjaga peralatan dan perlengkapan serta lingkungan kerja.

f. Disiplin

Kehadiran seorang pegawai juga akan menjadi bahan pertimbangan. Hal yang berhubungan dengan kedisiplinan adalah hal penting bagi perusahaan maupun pegawai.

Kriteria Penilaian Kompetensi Individu

\begin{tabular}{|c|c|l|c|}
\hline Penilaian & Poin & \multicolumn{1}{|c|}{ Derajat Penilaian Kompetensi Individu } \\
\hline Panutan & 500 & $\begin{array}{l}\text { Pencapaian unjuk kerja pegawai dengan } \\
\text { menunjulkan perlakuan yang konsisten, menjadi } \\
\text { panutan, senantiasa menyumbang kearah kemajuan } \\
\text { penusahaan secara keselunıhan }\end{array}$ \\
\hline Selalu & 400 & $\begin{array}{l}\text { Pencapaian unjuk keija pegawai dengan } \\
\text { menunjukkan perlakuan yang konsisten dan menjadi } \\
\text { contoh yang baik }\end{array}$ \\
\hline Sering & 300 & $\begin{array}{l}\text { Pencapaian unjuk kerja pegawai dengan } \\
\text { menunjukkan kompetensi namun belum merupakan } \\
\text { kekuatan potensial }\end{array}$ \\
\hline Jarang & 200 & $\begin{array}{l}\text { Pencapaian unjuk kerja pegawai dengan jarang } \\
\text { menujukkaukumpetensi }\end{array}$ \\
\hline $\begin{array}{c}\text { Tidak } \\
\text { Pcrnah }\end{array}$ & 100 & $\begin{array}{l}\text { Pencapaian unjuk kerja pegawai dengan tidak } \\
\text { menunjukkan kompctcnsi yang diharapkan }\end{array}$ \\
\hline
\end{tabular}

Tabel 6 merupakan kriteria peniaian kompetensi individu, penilaian tersebut berdasarkan pengisian atasan pada kuesioner online. Setelah itu aplikasi akan menunjukkan hasil penilaian berdasarkan kriteria penilaian kompetensi individu. Hasil akhir penilaian kompetensi individu dapat dilihat pada tabel 7.

Hasil Penilaian Kompetensi Individu

\begin{tabular}{|c|l|l|}
\hline $\begin{array}{c}\text { Rentang Poin } \\
\text { Kompetensi } \\
\text { Individu }\end{array}$ & Hasil Penilaian Kompetensi Individu & Simbol \\
\hline $401-500$ & Kompetensi Istimewa & Kom-1 \\
\hline $301-400$ & Kompetensi Selalu Ditampilkan & Kom-2 \\
\hline $201-300$ & Kompetensi Sering Ditampilkan & Kom-3 \\
\hline $100-200$ & Kompetensi Jarang Ditampilkan & Kom-4 \\
\hline
\end{tabular}

Setelah itu didapatkan hasil penilaian berdasarkan rentang nilai kompetensi individu, apakah pegawai mendapatkan kompetensi istimewa, kompetensi selalu ditampilkan, kompetensi sering 
ditampilkan atau kompetensi jarang ditampilkan. Dalam penilaian ini dimisalkan Bapak Taufik mendapatkan poin 430, berarti beliau mendapatkan nilai "Kompetensi Istimewa"

Jika sudah dilaksanakan penilaian sasaran kinerja dan kompetensi individu, maka penilaian terakhir akan dilakukan untuk mengetahui nilai akhir pegawai selama satu semester. Nilai akhir semester merupakan nilai sasaran kinerja (NSK) ditambah dengan nilai kompetensi individu (NKI). Nilai akhir pegawai dapat dilihat pada tabel berikut.

Penilaian Akhir Kinerja Pegawai Semester

\begin{tabular}{|c|c|c|c|c|c|}
\hline \multirow{2}{*}{$\begin{array}{c}\text { Hasil } \\
\text { Pengukuran } \\
\text { Kompetensi } \\
\text { Individu }\end{array}$} & \multicolumn{5}{|c|}{ Hasil Pengukuran Sasaran Kinerja } \\
\hline & Marginal & $\begin{array}{c}\text { Need } \\
\text { Improvement }\end{array}$ & $\begin{array}{l}\text { Meet } \\
\text { requirements }\end{array}$ & $\begin{array}{c}\text { Exceeds } \\
\text { requirements }\end{array}$ & Outstanding \\
\hline Kom-1 & & & & $\begin{array}{l}\text { Sangat } \\
\text { Potensial }\end{array}$ & Luar biasa \\
\hline Kom-2 & & \multirow{2}{*}{$\begin{array}{l}\text { Kandidat } \\
\text { Potensial }\end{array}$} & \multirow{2}{*}{ Potensial } & \multirow{2}{*}{ Optimal } & $\begin{array}{l}\text { Sangat } \\
\text { Optimal }\end{array}$ \\
\hline Kom-3 & $\begin{array}{c}\text { Perlu } \\
\text { Perhatian }\end{array}$ & & & & \\
\hline Kom-4 & $\begin{array}{c}\text { Sangat Perlu } \\
\text { perhatian }\end{array}$ & $\begin{array}{c}\text { Perlu } \\
\text { Penyesuaian }\end{array}$ & & & \\
\hline
\end{tabular}

Dari tabel diatas dapat disimpulkan bahwa titik temu antara nilai hardskill dengan nilai softskill pegawai atau antara Nilai Sasaran Kinerja (untuk selanjutnya disingkat NSK) dan Nilai Kompetensi Individu (untuk selanjutnya disingkat NKI) adalah nilai akhir yang didapatkan pegawai. Jika NSK ER dan NKI Kom-1 maka akan mendapatkan sangat potensial. Jika nilai yang didapatkan pegawai antara NSK OS dan NKI Kom-1, maka akan mendapatkan luar biasa. Jika NSK OS dan NKI Kom-2, maka akan mendapatkan nilai sangat optimal. Jika NSK ER dan NKI KOM-2 dan Kom-3, maka nilainya adalah optimal. Jika NSK MR dan NKI Kom- 2 dan Kom-3, maka hasilnya adalah Potensial. Jika NSK NI dan NKI Kom-2 dan Kom-3, maka nilainya adalah Kandidat potensial. Jika NSK NI namun NKI Kom-4, maka nilainya adalah perlu penyesuaian. Untuk nilai terendah adalah yang mendapatkan NSK MG dan NKI Kom-3 dan Kom-4 dengan nilai Perlu perhatian dan Sangat perlu perhatian. Dalam kasus ini dapat diketahui bahwa nilai akhir Bapak Taufik adalah Luar Biasa karena beliau mendapatkan nilai 68 sasaran kinerja "Outstanding" dan nilai kompetensi individu "Istimewa". Setelah nilai akhir seluruh pegawai ditentukan akan terbit satu SK (Surat Keputusan).

\section{Masalah atau Kendala}

Dalam melakukan penilaian kinerja, tentunya ada permasalahan atau kendala yang dihadapi. Masalah atau kendala adalah hal yang umum ditemui dalam setiap penilaian. Berdasarkan hasil observasi yang dilakukan Penulis, penilaian kinerja pegawai pada PT PLN (Persero) Wilayah Maluku dan Maluku Utara juga terdapat masalah dan kendala.

1. Hasil yang diperoleh dari kuesioner tersebut dapat di simpulkan bahwa dari 91 sampel yang di ambil untuk menjawab 6 pertanyaan yang di ajukan terkait implementasi sistem penilaian kinerja dengan aplikasi SIMKPNAS apakah sudah berjalan dengan baik atau belum, pertanyaan diajukan kepada Manajer, Asisten Manajer dan Staf berikut komposisinya sebagai berikut.

Komposisi jumlah sampel sesuai jabatan

\begin{tabular}{|c|c|c|c|}
\hline No. & Jabatan & Bidang & Jumlah \\
\hline \multirow{6}{*}{1} & \multirow{6}{*}{ Manajer } & Bidang Perencanaan & 2 \\
\hline & & \begin{tabular}{|l|} 
Bidang SDM dan Umum \\
\end{tabular} & 4 \\
\hline & & Bidang Teknik & 4 \\
\hline & & \begin{tabular}{|l|} 
Bidang Keuangan \\
\end{tabular} & 3 \\
\hline & & \begin{tabular}{|l} 
Bidang Niaga \\
\end{tabular} & 2 \\
\hline & & Biro K3L & 1 \\
\hline \multicolumn{3}{|c|}{ Jumlah } & 16 \\
\hline \multirow{5}{*}{2} & \multirow{5}{*}{ Asisten Manajer } & Bidang SDM dan Umum & 8 \\
\hline & & Bidang Teknik & 8 \\
\hline & & Bidang Keuangan & 5 \\
\hline & & \begin{tabular}{|l|} 
Bidang Niaga \\
\end{tabular} & 5 \\
\hline & & Biro K3L & 2 \\
\hline \multirow{7}{*}{3} & & umlah & 28 \\
\hline & \multirow{6}{*}{ Staf } & Bidang Perencanaan & 7 \\
\hline & & Bidang SDM dan Umum & 11 \\
\hline & & Bidang Teknik & 11 \\
\hline & & \begin{tabular}{|l} 
Bidang Keuangan \\
\end{tabular} & 7 \\
\hline & & \begin{tabular}{|l} 
Bidang Niaga \\
\end{tabular} & 9 \\
\hline & & Biro K3L & 2 \\
\hline \multicolumn{3}{|c|}{ Jumlah } & 47 \\
\hline \multicolumn{3}{|c|}{ Jumlah Total } & 91 \\
\hline
\end{tabular}


Hasil yang diperoleh adalah sebanyak $17 \%$ menjawab tidak setuju, 34\% menjawab kurang setuju, $22 \%$ menjawab cukup setuju dan $22 \%$ menjawab setuju serta 5\% menjawab sangat setuju, sehingga dapat disimpulkan sistem penilaian kinerja belum berjalan dengan baik dikarenakan yang menjawab tidak setuju sampai cukup setuju sebanyak $73 \%$ dan yang menjawab setuju dan sangat setuju sebanyak $23 \%$.

Hasil Rekap Pertanyaan Kuesioner

\begin{tabular}{|l|l|r|r|r|r|r|r|}
\hline No. & \multicolumn{1}{|c|}{ Pertanyaan } & $\begin{array}{r}\text { Tidak } \\
\text { Setuju }\end{array}$ & $\begin{array}{c}\text { Kurang } \\
\text { Setuju }\end{array}$ & $\begin{array}{c}\text { Cukup } \\
\text { Setuju }\end{array}$ & Setuju & $\begin{array}{c}\text { Sangat } \\
\text { Setuju }\end{array}$ & Jumlah \\
\hline 1 & Apakah Saudara tahu apa itu SIMKPNAS & 0 & 10 & 7 & 54 & 20 & 91 \\
\hline 2 & $\begin{array}{l}\text { Apakah Saudara memahami tentang penilaian kinerja } \\
\text { dengan SIMKPNAS }\end{array}$ & 0 & 18 & 42 & 28 & 3 & 91 \\
\hline 3 & Apakah Sosialisasi sering dilakukan & 0 & 52 & 26 & 11 & 2 & 91 \\
\hline 4 & $\begin{array}{l}\text { Apakah Penerapan penilaian kinerja dengan } \\
\text { SIMKPNAS sudah berialan dengan baik }\end{array}$ & 11 & 30 & 32 & 14 & 4 & 91 \\
\hline 5 & $\begin{array}{l}\text { Apakah terdapat perbedaan bobot dari target kinerja } \\
\text { setian negawai }\end{array}$ & 59 & 32 & 0 & 0 & 0 & 91 \\
\hline 6 & Bagaimana penerapan kouta dalam penilaian kinerja & 21 & 42 & 16 & 12 & 0 & 91 \\
\hline
\end{tabular}

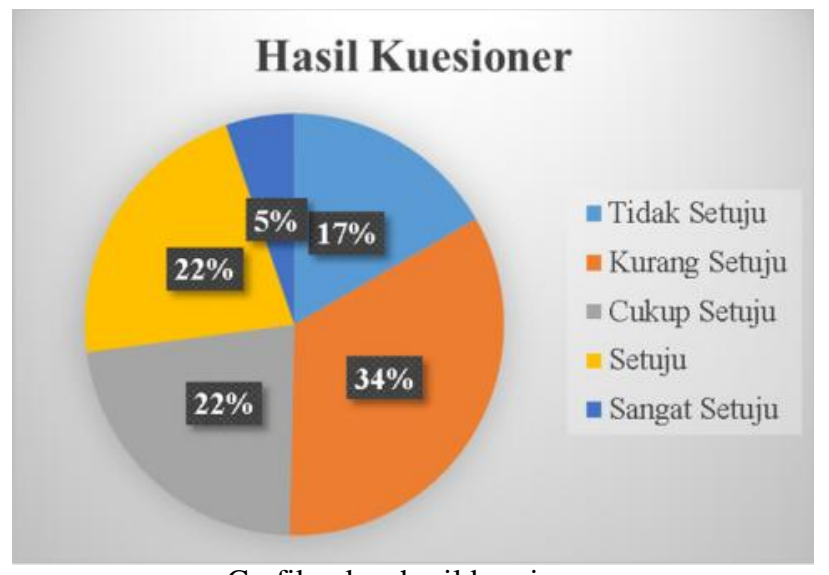

Grafik rekap hasil kuesioner

Dari hasil penelitian pada tabel 10 pertanyaan nomor 4 dapat disimpulkan sebanyak $80 \%$ pegawai dinilai tidak sesuai dengan hasil yang dicapai dan hanya $20 \%$ yang sesuai, kebanyakan pegawai di nilai dengan poin 201-300 atau disebut potensial atau memenuhi harapan (kurang baik), sedangkan penilaian kinerja yang baik pencapaian poin adalah 301 sampai dengan 400 dikatakan optimal atau melampaui harapan (baik) dan 401 sampai dengan 500 adalah pencapaian luar biasa (baik sekali).

2. Wawancara dilakukan kepada pegawai mengenai sistem penilaian kinerja karyawan yang ada, serta siapa saja pihak yang berwenang melakukan penilaian atau pengawasan pada PT PLN (Persero) Wilayah Maluku dan Maluku Utara. Kesimpulan dari hasil wawancara sebagai berikut:

a. Kurangnya sosialisasi tentang prosedur penilaian.

b. Belum adanya perbedaan bobot pekerjaan dalam aplikasi SIMKPNAS secara spesifik.

c. Ada kuota (peer assessment) sehingga nilai pegawai yang sudah sesuai dengan kinerjanya harus direvisi kembali.

3. Observasi, untuk mengamati secara langsung aktivitas inisiasi KPI, pengisian target dan realisasi yang berlangsung di PT PLN (Persero) Wilayah Maluku dan Maluku Utara. Sebagai contoh hasil perbandingan penilaian kinerja pegawai yang menunjukkan penilaian tidak berjalan dengan baik. 


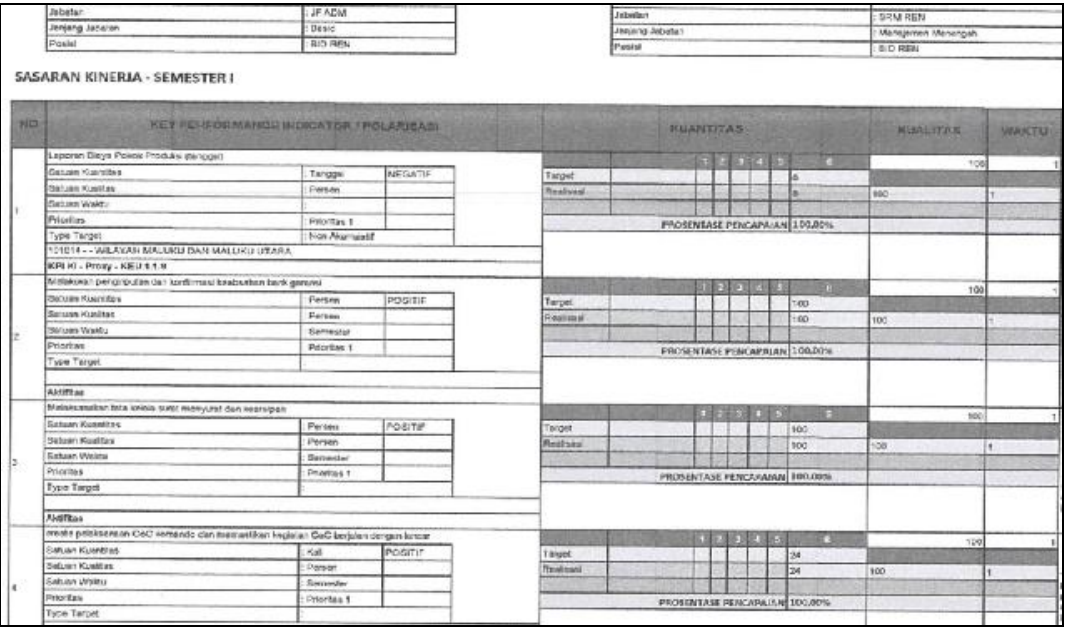

Realisasi kinerja pegawai A

Hasil penilaian kinerja pegawai A

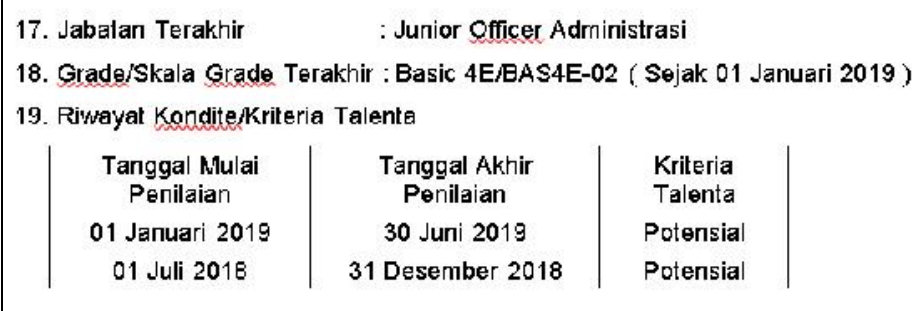

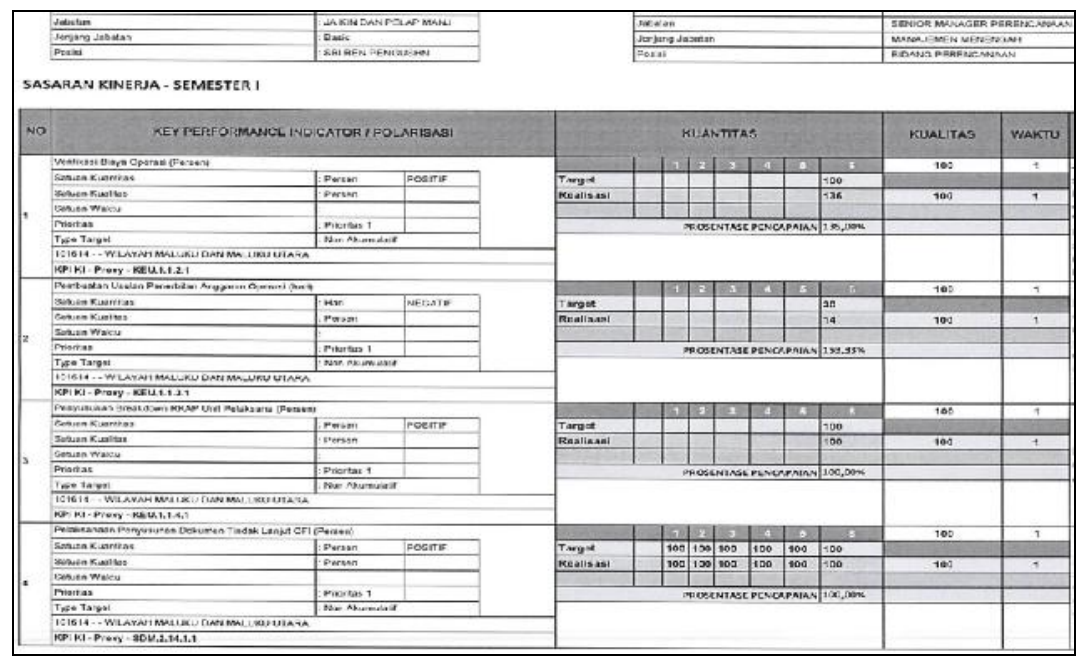

Realisasi kinerja pegawai B

Hasil penilaian kinerja pegawai B

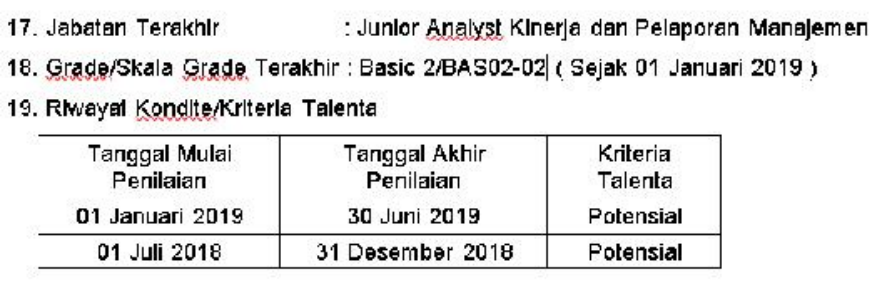




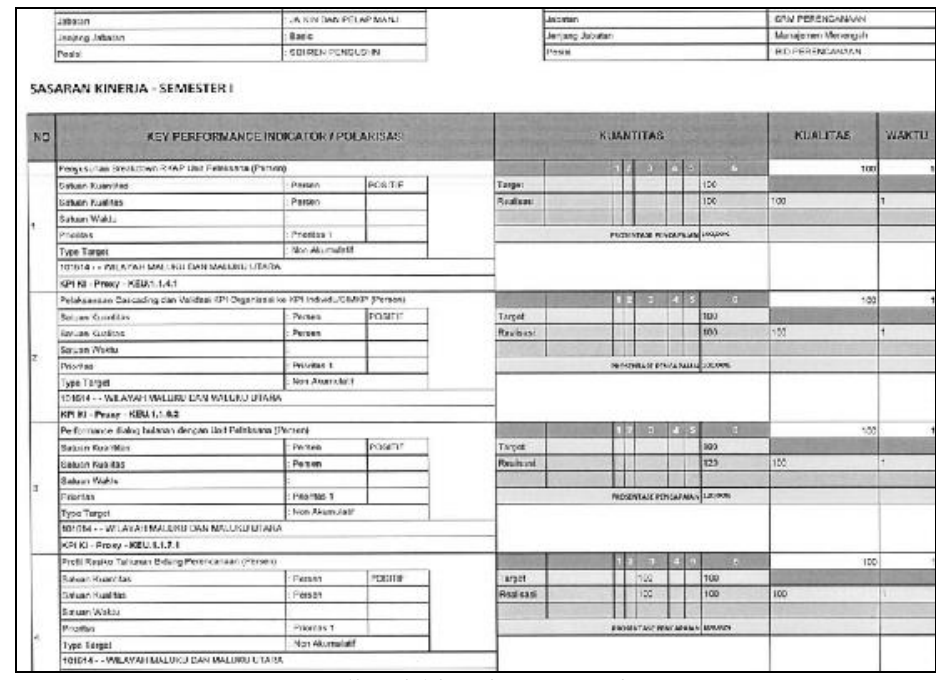

Realisasi kinerja pegawai C

Hasil penilaian kinerja pegawai $\mathrm{C}$

\begin{tabular}{|c|c|c|c|}
\hline $\begin{array}{l}\text { 17. Jabatan Terakhlr } \\
\text { 18. Grade/Skala Grade } \\
\text { 19. Riwayal Kondite/Krit }\end{array}$ & \multicolumn{3}{|c|}{ : Junior Anabyst KInerja dan Pelaporan Manajemen } \\
\hline $\begin{array}{l}\text { Tanggal Mulai } \\
\text { Penillalan }\end{array}$ & $\begin{array}{l}\text { Tanggal Akhir } \\
\text { Penllalan }\end{array}$ & $\begin{array}{l}\text { Kriteria } \\
\text { Talenta }\end{array}$ & \\
\hline 01 Januari 2019 & 30 Juni 2019 & Potensial & \\
\hline 01 Juli 2018 & 31 Desember 2018 & Potensial & \\
\hline
\end{tabular}

Berdasarkan data hasil penilaian pegawai A, B dan C, jika dilakukan perhitungan penilaian akhir pegawai menggunakan acuan kriteria penilaian sasaran kinerja pada tabel 4.4, maka dari hasil perhitungan yang diperoleh pegawai A mendapat poin 300 (potensial), pegawai B mendapat nilai 317 (optimal) dan pegawai C mendapat point 308 (optimal) tetapi pada kenyataannya pegawai $\mathrm{A}, \mathrm{B}$ dan $\mathrm{C}$ tetap di nilai sama yaitu 300 point (potensial).

Perbandingan hasil penilaian

\begin{tabular}{|c|c|c|c|c|c|l|c|}
\hline \multirow{2}{*}{ No. } & \multirow{2}{*}{ Sampel } & \multicolumn{3}{|c|}{ Hasil Penilaian } & \multirow{2}{*}{ Nilai } & \multirow{2}{*}{ Penilaian } & \multirow{2}{*}{ Kriteria Talenta } \\
\cline { 3 - 5 } & & Waktu & Kualitas & Kuantitas & Rata-rata & & \\
\hline 1 & $\mathrm{~A}$ & 300 & 300 & 300 & 300 & Memenuhi Harapan & Potensial \\
\hline 2 & $\mathrm{~B}$ & 300 & 300 & 350 & 317 & Melampaui Harapan & Optimal \\
\hline 3 & $\mathrm{C}$ & 300 & 300 & 325 & 308 & Melampaui Harapan & Optimal \\
\hline
\end{tabular}

\section{Pembahasan}

Setelah meneliti mengenai pelaksanaan SIMKPNAS di PLN Wilayah MMU, dalam penelitian ini juga dicari kelemahan dari SIMKPNAS itu sendiri. Mengenai kesesuaian hasil penilaian, dapat disimpulkan bahwa masih banyak pegawai yang merasa penilaian kinerja dengan SIMKPNAS ini belum berjalan dengan baik dan hasil penilaiannya belum sesuai dengan kinerja pegawai sesungguhnya. karena ada kuota (peer assessment) sehingga nilai pegawai yang sudah sesuai dengan kinerjanya harus direvisi kembali, alasan lain yaitu belum adanya perbedaan bobot pekerjaan dalam aplikasi SIMKPNAS secara spesifik.

Prosedur penilaian yang cukup rumit tentunya tidak sedikit pegawai yang masih kurang paham dengan penilaian kinerja. Sebagian besar pegawai yang masih kurang paham adalah pegawai baru. Bagi sebagian pegawai penilaian kinerja hanyalah formalitas belaka, sehingga tidak terlalu penting untuk dilakukan. Padahal hasil penilaian kinerja secara tidak langsung berpengaruh terhadap kenaikan gaji pegawai. Untuk pengisian sasaran kinerja, pegawai baru lebih memilih melihat sasaran kinerja lama yang dibuat oleh pegawai senior, dibandingkan membuat sasaran kinerja baru berdasarkan KPI yang ada. Hal ini disebabkan karena keterbatasan pemahaman terhadap penilaian kinerja. 
Penilaian kinerja pada PT PLN (Persero) diharapkan memberikan sosialisasi yang baik tentang prosedur penilaian kinerja sehingga semua pegawai dapat mengerti dan memahami prosedur penilaian tersebut demi tercapainya tujuan organisasi. Mengakomodir perbedaan bobot pekerjaan, sehingga tidak hanya melihat apakah target tercapai atau tidak, tetapi dapat memberikan bobot seberapa besar usaha untuk mencapai target tersebut.

Adanya kuota (peer assessment) membuat banyak pegawai merasa hasil penilaian kerja SIMKPNAS belum sesuai. Sebaiknya tidak ada kuota (peer assessment), jadi pegawai yang kinerjanya baik dinilai baik, tidak dikurangi karena kuota. Hal ini tentu harus disertai dengan pegawai struktural menilai bawahan secara berjenjang, sehingga sudah terengking dari awal penilaian. Tiap pegawai diharapkan memiliki kesadaran untuk mengisi sendiri SIMKPNAS, tidak menyepelekan aplikasi penilaian kinerja yang sudah dibangun dengan baik ini. Hal ini tentu harus didorong dengan perhatian dan himbauan dari pihak manajemen.

\section{KESIMPULAN}

Dari uraian yang telah dijelaskan pada bab sebelumnya dan berdasarkan penelitian yang dilakukan oleh Penulis pada PT PLN (Persero) Wilayah Maluku dan Maluku Utara, maka dapat disimpulkan bahwa:

1. Penilaian kinerja karyawan pada PT PLN (Persero) ada dua macam yakni hardskill dan softskill. Kedua jenis penilaian tersebut menggunakan aplikasi SIMKPNAS dan penilaian kinerja dalam penelitian ini ialah di tentukan dengan poin. Dari hasil penelitian sebanyak $80 \%$ pegawai dinilai tidak sesuai dengan hasil yang dicapai atau tidak berjalan dengan baik dan hanya $20 \%$ yang sesuai.

2. Kurangnya sosialisasi tentang penilaian kinerja sehingga banyak pegawai yang belum mengerti dan memahami prosedur penilaian tersebut dan belum mengakomodir perbedaan bobot pekerjaan, sehingga tidak hanya melihat apakah target tercapai atau tidak, tetapi dapat memberikan bobot seberapa besar usaha untuk mencapai target tersebut.

3. Adanya kuota (peer assessment) membuat banyak pegawai merasa hasil penilaian kerja SIMKPNAS belum sesuai. Sebaiknya tidak ada kuota (peer assessment), jadi pegawai yang kinerjanya baik dinilai baik, tidak dikurangi karena kuota. Hal ini tentu harus disertai dengan pegawai struktural menilai bawahan secara berjenjang, sehingga sudah teranking dari awal penilaian. Tiap pegawai diharapkan memiliki kesadaran untuk mengisi sendiri SIMKPNAS, tidak menyepelekan aplikasi penilaian kinerja yang sudah dibangun dengan baik ini. Hal ini tentu harus didorong dengan perhatian dan himbauan dari pihak manajemen

\section{DAFTAR PUSTAKA}

Dessler, Gary. (2000) Human Resource Management. London : Prentice-Hall International.

Goodale, J. G. (1992) Improving performance appraisal. Business Quarterly. 57(2).p.65.

Handoko, T. Hani. (2000) Manajemen Personalia dan Sumber daya Manusia. Yogyakarta: BPFE Yogyakarta.

Hasibuan, Malayu S P. (2012). Manajemen Sumber Daya Manusia . Jakarta: Bumi Aksara.

Murwaningsih, Tri. (2005). Manajemen Sumber Daya Manusia . Surakarta: UNS Press.

Nazir, Moh. (2005). Metode Penelitian. Bogor: Ghalia Indonesia.

Panggabean, Mutiara S. (2003). Manajemen Sumber Daya Manusia. Jakarta: Ghalia Indonesia. .Peraturan Direksi PT PLN (Persero) nomor. 0045.P.DIR.2017 Sistem Manajemen Kinerja

Pegawai

Rachmawati, Kusdyah Ike.( 2007)., Manajemen Sumber Daya Manusia. Yogyakarta: CV. Andi Offset

Siagian, Sondang. P. (2003). Teori dan Praktek Kepemimpinan. Jakarta: Rineka Cipta

Siagian, Sondang. P. (2012). Manajemen Sumber Daya Manusia. Jakarta: Bumi Aksara

Sarwono, Jonathan. (2006). Metode Penelitian Kuantitatif dan Kualitatif. Yogyakarta: Graha Ilmu.

Sastrohadiwiryo, Siswanto. B. (2003). Manajemen Tenaga Kerja Indonesia: Pendekatan Adminitratif dan Operasional . Jakarta: PT Bumi Aksara. 
